\title{
KRITIK SOSIAL DALAM CERPEN PELAJARAN MENGARANG KARYA SENO GUMIRA AJIDARMA MELALUI PENDEKATAN SEMIOTIKA PIERCE
}

\author{
Aprillia Ratna Sasmita \\ Universitas Negeri Yogyakarta \\ E-mail: aprilliaratnasasmita.ars@gmail.com
}

\begin{abstract}
Abstrak: Sebagai sebuah respon yang menginterpretasikan kepekaan pengarang terhadap berbagai fenomena di sekitarnya, karya sastra hadir dengan berbagai muatan kritik, nilai, dan norma. Cerpen Pelajaran Mengarang karya Seno Gumira Ajidarma merupakan salah satu karya sastra yang hadir dengan muatan nilai-nilai dan kritik sosial untuk merespon realitas kehidupan lain masyarakat marjinal ibukota. Tujuan penelitian ini adalah untuk mengetahui kritik sosial pada cerpen Pelajaran Mengarang karya Seno Gumira Ajidarma dengan menggunakan pendekatan semiotika tanda Pierce pada objek trikotomi relasi (makna) berupa ikon, indeks, dan simbol. Penelitian ini menggunakan pendekatan deskriptif kualitatif dengan metode analisis isi (studi pustaka). Metode pengumpulan data pada penelitian ini meliputi kegiatan membaca, mengidentifikasi, mencatat, dan menafsirkan data dengan teknik analisis data deskriptif kualitatif berupa studi pustaka (analisis isi). Hasil penelitian yang diperoleh menunjukkan bahwa kritik sosial yang dihadirkan pengarang melalui cerpen Pelajaan Mengarang, ditinjau dari pendekatan semiotika Pierce mengenai tanda, yaitu ikon, indeks, dan simbol. Kritik sosial yang ditemukan antara lain: (1) kesalahan paradigma masyarakat tentang perkotaan; (2) status sosial pada masyarakat yang termarjinalkan bukanlah menjadi prioritas penting; dan (3) lingkungan sosial memiliki berbagai dampak kehidupan individu tersebut melekat pada karakter, tingkah laku, konflik batin, bahkan satuan bahasa yang digunakan oleh tokoh-tokoh di dalam cerpen.
\end{abstract}

Kata Kunci: karya sastra, cerpen, kritik sosial, semotika Pierce.

\section{SOCIAL CRITICISM IN THE SHORT STORY OF "PELAJARAN MENGARANG” BY SENO GUMIRA AJIDARMA THROUGH PIERCE SEMIOTIC APPROACH}

\begin{abstract}
As a response that interprets the author's sensitivity to the various phenomena around him, literary works come with a variety of criticisms, values, and norms. Seno Gumira Ajidarma's short story "Pelajaran Mengarang" is one of the literary works that comes with a content of values and social criticism to respond to the other realities of life of marginalized communities in the capital. The purpose of this study was to determine the social criticism of Seno Gumira Ajidarma's short story "Pelajaran Mengarang" by using the semiotic approach of Pierce's sign on the trichotomy object of relations (meaning) in the form of icons, indexes and symbols. This study used a qualitative descriptive approach with content analysis methods (literature study). Data collection methods in this study include reading, identifying, recording, and interpreting data using qualitative descriptive data analysis techniques in the form of literature studies (content analysis). The results obtained show that the social criticism presented by the author through the short story "Pelajaran Mengarang" is viewed from Pierce's semiotic approach to signs, namely icons, indexes, and symbols. The social criticisms found include: (1) the wrong paradigm of urban society; (2) social status in marginalized communities is not an important priority; and (3) the social environment has
\end{abstract}

BASASTRA Jurnal Bahasa, Sastra, dan Pengajarannya

Volume 9 Nomor 1, April 2021, P-ISSN 2302-6405, E-ISSN 2714-9765 
various impacts on the individual's life which is attached to the character, behavior, inner conflict, even the language unit used by the characters in the short story.

Keywords: literary works, short story, social criticism, Pierce's semiotics.

\section{PENDAHULUAN}

Sastra dikenal sebagai sebuah karya yang bertolak dari imaji atau khayalan pengarang sehingga bersifat imajinatif (Wellek \& Warren, 1993: 20). Karya sastra pada hakikatnya merupakan representasi kehidupan, hasil proses kreatif pengarang sebagai respon atau tanggapan dari berbagai fenomena yang melingkupinya. Peran seorang pengarang dalam penciptaan sebuah karya sastra memiliki kedudukan yang sangat penting dan krusial. Hal tersebut karena dalam penyusunan karya sastra dilandasi pengalaman-pengalaman hidup pada realitas bermasyarakat di dunia nyata dengan objek materi kajian berupa curahan masalah kehidupan sosial budaya. Itu sebabnya, setiap hal yang tertangkap oleh alat indra (pengecapan, pendengaran, perasaan, penciuman, dan perabaan) yang memiliki memori atau kedalaman kesan tertentu bagi pengarang akan mampu menjadi sebuah bahan kajian penciptaan karya sastra.

Salah satu jenis genre karya sastra adalah prosa. Prosa merupakan sebuah teks sejenis fiksi, naratif, atau wacana naratif. Cerpen atau cerita pendek merupakan salah satu bentuk prosa fiksi yang popular. Cerpen dalam karya sastra menampilkan kehidupan sebagai suatu kenyataan sosial mencangkup relasi antara individu, kelompok, dan peristiwa yang terjadi dalam batin seseorang (Damono, 1978: 1). Selain menampilkan kehidupan sebagai kenyataan sosial yang relevan, cerpen merupakan salah satu jenis prosa fiksi dengan plot dan jumlah kata yang ringkas, sehingga cerita dapat dibaca habis dalam waktu yang singkat (Nurgiyantoro, 2019: 2).

Sebagai sebuah hasil proses kreatif pengarang untuk dapat merespon suatu fenomena ataupun peristiwa dalam masyarakat, cerpen diciptakan dengan membawa sebuah pesan, nilai, dan amanat yang sekaligus dapat menjadi sarana atau media untuk menyuarakan sebuah kritik berdasarkan fenomena-fenomena tertentu kepada masyarakat kultur di Indonesia. Hal tersebut selaras dengan objek yang menjadi fokus kajian ini yaitu kritik sosial pada cerpen Pelajaran Mengarang karya Seno Gumira Ajidarma. Sugiwardana (2014) mendefinisikan kritik sosial sebagai salah satu bentuk komunikasi, khususnya pada masyarakat tutur yang sekaligus berfungsi untuk menjadi kontrol atau kendali dalam jalannya suatu sistem sosial.

Salah satu kedalaman pesan berupa kritik sosial terlihat dalam esensi isi cerpen Pelajaran Mengarang karya Seno Gumira Ajidarma yang dengan keras menghardik paradigma mengenai kultur (budaya) masyarakat 
marjinal di Indonesia. Secara singkat, cerpen ini menceritakan mengenai kehidupan seorang anak perempuan, bernama Sandra, yang tinggal dan tumbuh di sebuah lingkungan dengan latar sosial masyarakat marjinal ibukota. Permasalahan yang dihadirkan sejak awal cerita mengenai pelajaran mengarang merupakan benang merah yang menghubungkan setiap peristiwa mengenai kehidupan keras Sandra. Ia tumbuh dan dibesarkan oleh seorang wanita yang bekerja sebagai seorang penghibur di lingkungan sosial yang keras, kumuh bahkan dianggap hina oleh masyarakat awam.

Fakta-fakta mengenai keadaan sosial dan kehidupan masyarakat marjinal, sisi lain dari perjuangan seorang wanita untuk dapat memenuhi serta mencukupi kebutuhan hidup, hingga dampak kerasnya lingkungan tersebut terhadap pertumbuhan dan perkembangan seorang anak, merupakan inti objek kajian kritik sosial pada cerpen. Penjelasan dan penjabaran mengenai kritik sosial dalam cerpen tersebut dapat diungkapkan melalui teori semiotika Charles Sanders Pierce.

Kajian ini bertujuan untuk dapat mengetahui, mendeskripsikan:

tanda (dalam hubungan dengan objek) meliputi ikon, indeks, dan simbol dalam cerpen Pelajaran Mengarang karya Seno Gumira Ajidarma. (2) makna tanda berupa ikon, indeks, dan simbol dalam cerpan Pelajaran Mengarang karya Seno Gumira
Ajidarma dengan menggunakan pendekatan semiotika Pierce.

Represetamen

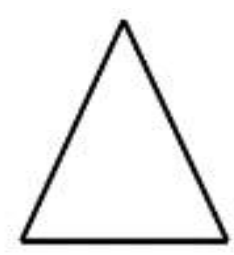

Objek Interpretan

Gambar 1. Model Segitiga Makna

Charles Sanders Pierce

(Sumber: Piliang, 2010)

Charles Sanders Pierce adalah salah satu filsuf berkembangsaan Amerika yang paling orisinil dan multidimensional. Pierce terkenal dengan teori tandanya yang memiliki prinsip dasar bahwa tanda bersifat representatif karena merupakan sesuatu yang mewakili sesuatu yang lain (something that represent something else). Titik sentral kajian semiotika Pierce adalah trikotomi relasi tiga unsur tanda yaitu hubungan antara represetamen, objek, dan interpretan atau yang juga dikenal sebagai model segitiga makna sebagai berikut. Fokus kajian yang akan digunakan untuk menelaah dan menjabarkan kritik sosial pada cerpen Pelajaran Mengarang karya Seno Gumira Ajidarma adalah unsur objek pada trikotomi relasi tanda Pierce.

Ditinjau dari hubungan yang terdapat antara representamen dengan objeknya, yakni sebagai hubungan yang 'menggantikan' atau 'the standing for relation', tanda-tanda oleh Pierce diklasifikasikan menjadi ikon (icon), indeks (index), dan simbol (symbol). Pierce berpendapat bahwa trikotomi 
tersebut merupakan sarana, media, atau alat pembagian tanda yang paling fundamental. Ikon merupakan tanda yang memiliki sifat persamaan bentuk alamiah antara hubungan penanda dan petandanya. Indeks diartikan sebagai sebuah tanda yang menunjukkan hubungan alamiah bersifat klausal (hubungan yang memiliki sifat timbal balik-sebab akibat). Sobur (2006) mendefinisikan simbol sebagai sebuah tanda yang menunjukkan adanya hubungan alamiah antara penanda dan petandanya yang bersifat arbitrer.

\section{METODE}

Penelitian ini adalah penelitian desktiptif kualitatif dengan menggunakan metode analisis isi (studi pustaka). Objek material pada kajian penelitian ini adalah cerpen Pelajaran Mengarang karya Seno Gumira Ajidarma. Data penelitian ini berupa kata, frasa, kalimat atau paragraf yang menunjukkan adanya kritik sosial yang disampaikan secara tersirat melalui kehidupan Sandra sebagai salah satu contoh kerasnya kehidupan masyarakat marjinal untuk dapat memenuhi kebutuhan hidup.

Metode pengumpulan data pada penelitian ini meliputi kegiatan membaca, mengidentifikasi, mencatat, dan menafsirkan data. Adapun langkah-langkah yang dilakukan dalam pengumpulan data meliputi kegiatan (1) membaca dan memahami isi dan inti cerita dari cerpen Pelajaran Mengarang karya Seno Gumira Ajidarma secara intensif; mengidentifikasi bagian-bagian tertentu dalam cerpen sebagai data yang diperlukan untuk mengkaji cerpen dengan pendekatan semiotika Pierce; (3) mencatat hasil identifikasi data berupa kutipan-kutipan baik berupa frasa, kalimat, maupun paragraf; (4) mengategorikan data yang telah terkumpul berdasarkan jenis dan karakteristik tanda menurut semiotika Pierce; (5) menganalisis, menginterpretasi, dan menafsirkan data untuk disajikan dan ditarik kesimpulannya.

Teknik analisis data dilakukan dengan menggunakan metode analisis isi (studi pustaka) pada cerpen Pelajaran Mengarang, karya Seno Gumiro Ajidarma. Analisis isi (studi pustaka) dilakukan dengan cara menginterpretasi data-data yang telah diperoleh dalam cerpen berdasarkan kesesuaiannya dengan pembahasan penelitian untuk dapat mengetahui adanya kritik sosial pada cepen tersebut ditinjau dari pendekatan semiotika tanda Pierce, yaitu ikon, indeks, dan simbol.

\section{HASIL DAN PEMBAHASAN}

Hasil dari kajian penelitian ini adalah bahwa di dalam Cerpen Pelajaran Mengarang, karya Seno Gumiro Ajidarma, pengarang membangun paradigma mengenai kritik sosial yang banyak ditemukan pada masyarakat marjinal ibukota. Kritik sosial tersebut dikaji berdasarkan analisis tanda dalam trikotomi relasi Pierce yang 
menekankan pada eksistensi dari berbagai fenomena sosial dan penyimpangan norma-norma masyarakat, khususnya norma asusila, yang serius namun kurang diperhatikan analisis tanda yang terdapat di dalam cerpen Pelajaran Mengarang karya Seno Gumira Ajidarma berupa simbol, ikon, indeks, dan dapat diketahui melalui tabel berikut.

Tabel 1. Analisis Ikon, Indeks, dan Simbol dalam Cerpen Pelajaran Mengarang karya Seno Gumiro Ajidarma

\section{Jenis Tanda \\ dalam}

Trikotomi

Pierce
Makna yang Dihasilkan

dari Analisis Tanda

\begin{tabular}{lll}
\hline Ikon & $\begin{array}{l}\text { Penggambaran keadaan lingkungan } \\
\text { rumah yang berantakan dan kumuh. }\end{array}$ \\
& $\begin{array}{l}\text { Penggambaran tempat kerja yang identik dengan } \\
\text { kondisi remang-remang dan dipenuhi aktivitas }\end{array}$ \\
& yang memuat unsur-unsur asusila. \\
& \\
& $\begin{array}{l}\text { Tingkah laku tokoh utama yang sering bepergian } \\
\text { untuk memenuhi pesanan dan jarang pulang } \\
\text { selama berhari-hari. }\end{array}$
\end{tabular}

Indeks $\quad$ Banyak menggunakan kosa kata makian dalam $\quad$ Status sosial yang rendah percakapan sehari-hari.

Penggambaran perilaku tokoh sebagai identitas Penyimpangan sosial diri sekaligus respon dari lingkungan sosial yang ditinggali. Penggambaran perilaku tokoh sebagai salah salah satu bentuk cara menjalankan pekerjaan atau profesi.

Adanya pergumulan batin yangmenandai adanya Gangguan psikologis krisis identitas.

\begin{tabular}{lll}
\hline Simbol & Perilaku menyimpang tokoh dalam & Gaya hidup \\
& kehidupan sehari-hari. Penggambaran & \\
& keadaan rumah yang berantakan. Pemenuhan & \\
& kebutuhan hidup yang tinggi (mahal). &
\end{tabular}

BASASTRA Jurnal Bahasa, Sastra, dan Pengajarannya

Volume 9 Nomor 1, April 2021, P-ISSN 2302-6405, E-ISSN 2714-9765 


\section{HASIL DAN PEMBAHASAN}

Berdasarkan identifikasi tanda dalam cerpen Pelajaran Mengarang karya Seno Gumira Ajidarma yang dilakukan dengan mengadaptasi jenisjenis tanda Pierce, diperoleh hasil bahwa terdapat tanda-tanda berupa ikon, indeks, dan simbol yang menunjukkan adanya makna penggambaran kritik sosial dalam cerpen tersebut.

\section{Ikon dalam Cerpen Pelajaran Mengarang Karya Seno Gumira Ajidarma}

Ikon sebagai hasil kajian cerpen Pelajaran Mengarang karya Seno Gumira Ajidarma dibedakan menjadi dua kategori yang berfungsi sebagai penanda lingkungan sosial dan sebuah profesi yaitu wanita penghibur atau wania malam. Ikon yang berfungsi sebagai penanda lingkungan sosial terlihat dari banyaknya kutipan di dalam cerpen yang merujuk pada tempat-tempat tertentu seperti rumah, kamar, dan 'tempat kerja'.

\section{Kutipan 1}

"Sandra hanya mendapatkan gambaran sebuah rumah yang berantakan. Botol-botol dan kalengkaleng minuman yang kosong berserakan di meja, di lantai, bahkan sampai ke atas tempat tidur. Tumpahan bir berceceran diatas kasur yang spreinya terseret entah ke mana. Bantal-bantal tak bersarung. Pintu yang tak pernah tertutup dan sejumlah manusia yang terus menerus mendengkur, bahkan ketika Sandra pulang dari sekolah." (Ajidarma, 1991)

Lingkungan sosial yang tergambar melalui citraan penglihatan dalam cerpen tersebut mengindikasikan bahwa rumah yang berantakan tersebut bukan merupakan keadaan yang tidak disengaja dan terjadi dalam waktu yang singkat, tetapi nyaris terjadi hampir setiap hari dibuktikan dengan adanya detail-detail seperti letak botol minuman keras yang ada di meja, tempat tidur yang berantakan dan pintu yang tidak pernah tertutup. Pintu yang tidak pernah tertutup juga mengindikasikan adanya faktor kesengajaan yang dimaksudkan untuk memudahkan tamu atau pelanggan bagi Ibu Sandra yang umumnya datang di malam hari.

Hal-hal tersebut sekaligus merujuk kepada fakta bahwa lingkungan tempat tinggal Sandra merupakan lingkungan sosial yang keras, yang juga dikategorikan sebagai pemukiman kumuh. Di perkotaan, pemukiman kumuh merupakan fenomena yang lekat dengan gemerlap penampakan ibukota. Biasanya pemukiman kumuh banyak ditinggali oleh masyarakat marjinal yang tinggal dengan berbagai penyimpangan sosial. Salah satu bentuk penyimpangan tersebut adalah adanya prostitiusi sebagai mata pencaharian, dibuktikan dengan adanya citraan pendengaran 'mendengkur' yang menunjukkan adanya eksistensi manusia (laki-laki) asing.

Umumnya di lingkungan sosial masyarakat yang masih mengedepankan 
nilai dan norma, pintu yang tidak ditutup pada malam hari akan menimbulkan stigma yang buruk atau bahkan stigma negatif sehingga dapat menyebabkan sanksi sosial berupa gunjingan. Bahkan minuman keras serta orang-orang asing yang menginap secara silih berganti merupakan suatu pemandangan tabu yang sangat dikecam dengan keras. Oleh karena itu, ikon pada kutipan tersebut menandakan fenomena lingkungan sosial yang keras di perkotaan dan biasanya ditandai oleh keberadaan kawasan kumuh seperti pada pemukiman di sekitar kolong jembatan, bantaran sungai, rel kereta, bahkan hingga pemukiman di sekitar TPA (tempat pembuangan akhir) yang masyarakatnya pada umumnya berpenghasilan rendah di bawah ratarata pendapatan per kapita masyarakat kota.

Lingkungan sosial tersebut mendukung adanya tempat-tempat hiburan yang biasa dimanfaatkan masyarakat sekitar sebagai ladang untuk dapat menghasilkan uang secara instan demi memenuhi gaya hidup dan meningkatkan status sosial di masyarakat.

\section{Kutipan 2}

"Di tempat kerja wanita itu, meskipun gelap, Sandra melihat banyak orang dewasa berpelukpelukan sampai lengket. Sandra juga mendengar musik yang keras, tapi Mami itu melarangnya nonton." (Ajidarma, 1991)

Berdasarkan kutipan tersebut ikon lingkungan sosial juga tampak pada tempat kerja Ibu Sandra yang merupakan rumah prostitiusi atau klub malam. Tempat yang remang-remang dengan banyak wanita dan pria saling berpelukan hingga menghilangkan sekat merupakan penanda sebuah tempat kerja yang sangat umum lekat dengan penyimpangan sosial norma dan nilai asusila.

Musik keras pada kutipan tersebut dapat menjadi tanda sebagai salah satu cara untuk menyiasati hal-hal yang terjadi di dalam tempat prostitusi tersebut. Oleh karena itu, pada cerpen Pelajaran Mengarang, Sandra yang merupakan siswi SD tidak diperbolehkan masuk karena memang tempat tersebut dikhususkan bagi orang-orang dewasa.

Ikon lingkungan sosial ini juga beresonansi dan berkorelasi dengan pekerjaan Ibu Sandra sebagai wanita malam yang tampak pada kutipan berikut.

Kutipan 3

"Sandra tahu, setiap kali pager ini menyebut nama hotel, nomor kamar, dan sebuah jam pertemuan, ibunya akan pulang terlambat. Kadang-kadang malah tidak pulang sampai dua atau tiga hari."

Kutipan tersebut menjadi sebuah ikon yang menandakan bahwa aktivitas atau kegiatan Ibu Sandra tersebut sangat lekat dengan kehidupan malam dan tempat-tempat privat seperti kamar hotel. Selain itu, keterangan waktu yang menyatakan bahwa pekerjaan tersebut sering dilakukan dengan memakan waktu lebih dari sehari juga mengindikasikan bahwa tamu atau pelanggan dari pekerjaan yang dilakoni 
oleh ibunya tidak hanya berasal dari orang-orang biasa saja, tetapi juga orang-orang berkantong tebal yang berani membayar mahal untuk mendapatkan kebahagiaan duniawi yang datang sekejap.

Oleh karena itu, ikon wanita malam sebagai sebuah profesi sangat lekat dengan wanita ataupun perempuan-perempuan muda yang tinggal di kawasan pemukiman dengan lingkungan sosial yang keras. Karena dengan demikian mereka dapat menghasilkan uang secara cepat (instan).

\section{Indeks dalam Cerpen Pelajaran Mengarang Karya Seno Gumiro Ajidarma}

Indeks diterjemahkan secara literal sebagai some sensory feature (sesuatu yang dapat dilihat, didengar, atau mudah tercium baunya) yang kemudian menghubungkannya dengan objek tertentu. Indeks juga dapat diartikan sebagai tanda yang menunjukkan adanya hubungan klausal atau sebab akibat. Berdasarkan hasil analisis cerpen Pelajaran Mengarang terdapat beberapa kategori indeks sebagai penanda adanya kritik sosial yang muncul di dalam cerpen tersebut, yaitu indeks status sosial yang rendah, penyimpangan sosial oleh masyarakat marjinal ibukota, dan dampaknya terhadap perkembangan psikologis anak.

Indeks sebagai tanda yang
menunjukkan makna mengenai
identitas masyarakat dengan status

sosial yang rendah ditunjukkan oleh kutipan-kutipan berikut.

Kutipan 1

"Diam, Anak Setan!" atau "Bukan urusanmu, Anak Jadah" atau "Sudah untung kamu ku kasih makan dan ku sekolahkan baik-baik. Jangan cerewet kamu, Anak Sialan!"

"Tentu saja punya, Anak Setan! Tapi, tidak jelas siapa! Dan kalau jelas siapa belum tentu ia mau jadi Papa kamu! Jelas? Belajarlah untuk hidup tanpa seorang Papa! Taik Kucing dengan Papa!"

Penggunaan bahasa sebagai satuan lingual yang umum digunakan dalam percakapan sehari-hari merupakan salah satu identitas dari status sosial yang melekat pada diri seseorang khususnya wanita. Semakin banyaknya penggunaan kosa kata kasar atau umpatan (memiliki makna negatif dan kurang sopan) yang digunakan oleh seorang wanita dalam komunikasinya, maka semakin rendah pula status sosial masyarakat tersebut ditinjau dari kacamata masyarakat kultur pada umumnya.

Lingkungan sosial yang menjadi penanda sekaligus pembentuk karakter masyarakat berperan besar dalam perkembangan lingustik seseorang, tidak terkecuali perkembangan linguistik pada cerpen Pelajaran Mengarang karya Seno Gumira Ajidarma. Dalam cerpen tersebut diketahui bahwa Ibu Sandra merupakan salah satu warga yang menetap dan bertempat tinggal di lingkungan sosial yang keras, karena itu perkembangan bahasanya cenderung mengikuti linguistik bahasa yang umumnya 
digunakan oleh penduduk kawasan tersebut. Karenanya bahasa yang digunakan pun memiliki interpretasi negatif.

Meskipun memang digunakan dalam konteks untuk meluapkan amarah atau emosi, tetapi kosa kata seperti pada kutipan cerpen tersebut hanya dapat ditemui di tengah masyarakat dengan norma sosial yang rendah sehingga memunculkan banyak perbendaharaan kata negatif. Selain itu, jika ditinjau lebih dalam, terdapat korelasi antara pekerjaan Ibu Sandra dengan penggunaan bahasa yang bermuara pada status sosialnya di masyarakat.

Sebagai seorang penghibur, status sosial Ibu Sandra dilihat dari pandangan masyarakat kultur termasuk status sosial yang rendah. Hal tersebut seolah kembali ditegaskan dengan perbendahaaraan kata yang ia gunakan untuk dapat berkomunikasi dalam kehidupan sehari-hari.

Sebagai bagian dari masyarakat marjinal ditinjau dari lingkungan sosial, tempat tinggal, bahkan pekerjaan yang dilakukan oleh Ibu Sandra, maka dapat diketahui bahwa aktivitas atau tindakan-tindakan tersebut bermuara pada penyimpangan sosial secara umum (general). Penyimpangan sosial tersebut dapat ditinjau lebih lanjut dari tindakantindakan yang dilakukan oleh beberapa wanita terhadap laki-laki asing yang mereka temui. Seperti terdapat pada kutipan cerpen berikut.
Kutipan 2

"Ia juga hanya berbisik malam itu, ketika terbangun karena dipindahkan ke kolong ranjang. Wanita itu barangkali mengira ia masih tidur. Wanita itu barangkali mengira, karena masih tidur maka Sandra tak akan pernah mendengar suara lenguhnya yang panjang maupun yang pendek di atas ranjang. Wanita itu juga tak mengira bahwa Sandra masih terbangun ketika dirinya terkapar tanpa daya dan lelaki yang memeluknya sudah mendengkur keras sekali."

Penyimpangan sosial yang jelas terlihat pada cerpen Pelajaran Mengarang adalah bahwa pekerjaan yang dilakukan oleh Ibu Sandra merupakan pekerjaan yang salah namun tetap dibenarkan oleh masyarakat di lingkungannya yang memiliki kesamaan nasib serupa. Penyimpangan sosial ini dapat ditinjau dari hilangnya peran norma-norma asusila baik dari perilaku Ibu Sandra dalam pekerjaannya yang selalu melibatkan kontak dengan lelaki asing, maupun melalui gaya hidup Ibunya yang selalu pulang malam dan mengonsumsi banyak minuman keras.

Kutipan 3

"Suatu malam wanita itu pulang merangkak-rangkak karena mabuk. Di ruang depan ia muntah-muntah dan tergelatak tidak bisa bangun lagi. Sandra mengepel muntahan-muntahan itu tanpa bertanya-tanya. Wanita yang dikenalnya sebagai ibunya itu sudah biasa pulang dalam keadaan mabuk."

Pengaruh dari adanya lingkungan sosial yang keras dan penyimpangan tersebut berdampak pada aspek psikologi 
pada anak yang dalam cerpen tersebut diwakilkan oleh kehadiran Sandra. Salah satu dampak yang nyata terlihat adalah hilangnya figur seorang ibu pada diri Sandra sebagai dampak dari berbagai faktor di antaranya adalah perilaku Marni-Ibu Sandra, yang tidak menunjukkan perilaku keibuan, hampir tidak pernah memberikan sentuhan afeksi untuk menunjukkan rasa kasih sayang kepada anaknya, serta kata-kata kasar dan umpatan yang lebih sering dilontarkan kepada Sandra dibandingkan kata-kata yang menunjukkan perasaan sayang. Serta juga ditambah oleh fakta yang menunjukkan bahwa Ibu Sandra sering melayani lebih dari satu lelaki.

Kutipan 4

"Sandra mencoba berpikir tentang "Ibu". Apakah ia akan menulis tentang ibunya? Sandra melihat seorang wanita yang cantik. Seorang wanita yang selalu merokok, selalu bangun siang, yang kalau makan selalu pakai tangan dan kaki kanannya selalu naik keatas kursi."

"Apakah wanita itu Ibuku?"

Pertanyaan retoris dalam kutipan tersebut menjadi penanda kebingungan batin yang berkecamuk dalam pikiran Sandra. Hal tersebut diperkuat oleh fakta bahwa sifat ibunya tidak dapat ia pahami karena sering berkata dan berperilaku kasar kepadanya, tetapi tidak jarang berbuat baik kepada Sandra. Hal-hal tersebut membuat eksistensi dan figur Ibu dalam pemikiran Sandra menjadi bias dan buram yang sekaligus menjadi penanda adanya gangguan psikologis pada diri
Sandra karena lingkungan sosial dan keluarga yang keras.

\section{Simbol dalam Cerpen Pelajaran Mengarang Karya Seno Gumiro Ajidarma}

Berdasarkan hasil identifikasi cerpen Pelajaran Mengarang simbol sebagai bagian dari kajian Trikotomi Relasi Pierce ditunjukkan oleh kutipankutipan berikut.

Kutipan 1

"Di ruang depan ia muntahmuntah dan tergelatak tidak bisa bangun lagi. Sandra mengepel muntahan-muntahan itu tanpa bertanya-tanya. Wanita yang dikenalnya sebagai ibunya itu sudah biasa pulang dalam keadaan mabuk." Kutipan 2

"Wanita itu juga tak mengira bahwa Sandra masih terbangun ketika dirinya terkapar tanpa daya dan lelaki yang memeluknya sudah mendengkur keras sekali."

Dari hasil analisis tersebut dapat diketahui adanya simbol yang menjadi penanda gaya hidup Sandra dan ibunya. Sandra yang masih merupakan seorang siswi SD harus selalu sabar menghadapi setiap tingkah laku ibunya yang selalu pulang malam, mabuk, dan terkadang tidur bersama pria asing. Hal tersebut karena tuntutan profesi ibunya yang bekerja sebagai wanita penghibur sehingga kehidupannya penuh dan lekat dengan minuman keras dan hubungan dengan banyak laki-laki asing.

Kutipan 3

"Sandra hanya mendapatkan gambaran sebuah rumah yang berantakan. Botol-botol dan kaleng- 
kaleng minuman yang kosong berserakan di meja, di lantai, bahkan sampai ke atas tempat tidur. Tumpahan bir berceceran diatas kasur yang spreinya terseret entah ke mana. Bantal-bantal tak bersarung. Pintu yang tak pernah tertutup dan sejumlah manusia yang terus menerus mendengkur, bahkan ketika Sandra pulang dari sekolah."

Gaya hidup lainnya juga tampak terlihat dari pernyataan mengenai keadaan fisik lingkungan rumah Sandra yang lekat dengan kata berantakan. Selain itu, hal-hal yang mengindikasikan sebagai peletak dasar berantakan tersebut terlihat dari berbagai botol minuman keras, keadaan tempat tidur yang selalu berantakan, dan pintu rumah yang tidak pernah tertutup agar kapan pun seorang pria ingin bermalam dengan ibunya tidak perlu mengetuk pintu terlebih dahulu dan menunggu.

Gaya hidup lainnya yang juga terlihat pada cerpen Pelajaran Mengarang karya Seno Gumira Ajidarma tersebut ditunjukkan oleh adanya gaya hidup masyarakat perkotaan yang konsumtif dan cenderung hidup mewah atau glamor.

Kutipan 4

"Setiap hari minggu wanita itu mengajaknya jalan-jalan ke plaza ini atau ke plaza itu."

Plaza atau mal merupakan suatu identitas tempat yang umumnya lekat dengan masyarakat konsumif dan burjois. Oleh karena itu, pada cerpen tersebut gaya hidup yang ditampilkan dan dimunculkan pengarang juga dimaksudkan untuk memberi gambaran mengenai usaha masyarakat marjinal di perkotaan dalam upaya memenuhi kebutuhan hidupnya, khususnya gaya hidup yang tinggi, demi menjaga, mempertahankan, maupun meningkatkan status sosial.

\section{Pembahasan Kritik Sosial pada Cerpen Pelajaran Mengarang Karya Seno Gumira Ajidarma}

Melalui hasil pembacaan cerpen dan analisis cerpen tersebut berdasarkan semiotika Pierce mengenai ikon, indeks, dan simbol terdapat beberapa jenis kritik sosial yang dapat ditemukan atau muncul.

Kritik sosial yang pertama membahas mengenai kesalahan paradigma masyarakat yang memandang bahwa kehidupan di kota adalah kehidupan dengan berlimpah pilihan dan peluang pekerjaan. Nyatanya, tidak semua penduduk kota mengalami kesejahteraan dan terdesak oleh pilihan untuk dapat melakukan segala cara demi dapat mencukupi kehidupan dan hidup dengan layak.

Kritik sosial yang kedua adalah bahwa status sosial pada masyarakat yang termarjinalkan di ibukota bukanlah menjadi prioritas penting, karena mereka lebih takut untuk tidak dapat menghidupi kehidupannya dengan layak daripada menjadi seorang berstatus sosial tinggi tetapi mlarat di kehidupannya.

Kritik sosial yang ketiga adalah bahwa lingkungan sosial memiliki berbagai dampak yang dapat cukup memberikan perombakan besar dalam kehidupan individu. Oleh karena itu, tidak jarang ada bahasa-bahasa slang 
yang lahir dan berkembang di suatu masyarakat dan menjadi identitas masyarakat tersebut. Selain itu, tidak dapat dipungkiri bahwa hal-hal tersebut dapat menjadi suatu awal dari adanya penyimpangan sosial di masyarakat yang kemudian dapat berdampak pada psikologis masyarakat itu sendiri.

Melalui cerpen Pelajaran Mengarang tersebut pengarang sekaligus mengkritisi pemikiran dan perilaku masyarakat Indonesia sebagai masyarakat kultur yang sangat memegang teguh norma dan nilai-nilai luhur. Tetapi pada kenyataannya, fenomena yang terjadi termasuk di dalamnya juga penyimpanganpenyimpangan sosial yang ada tidak dapat diatasi secara maksimal dan malah semakin menjamur serta mengakar di dalam masyarakat.

Masyarakat ibukota khususnya dan masyarakat Indonesia umumnya sudah terlalu puas untuk melabeli diri sebagai masyarakat yang berbudaya tetapi masih menutup mata terhadap berbagai fenomena yang menyangkut penyimpangan norma moral dan asusila. Sehingga penyimpanganpenyimpangan yang terjadi kemudian menjadi alasan terbentuknya permasalahan sosial yang bermuara pada sebuah penyimpangan budaya dengan pandangan atau stigma yang salah untuk membenarkan berbagai perbuatan tersebut sebagai tindakan yang lazim dan benar untuk dapat dilakukan.

\section{SIMPULAN}

Berdasarkan hasil kajian karya sastra tersebut dapat diketahui bahwa fenomena-fenomena sosial yang ada di dalam cerpen Pelajaran Mengarang tersebut dapat dianalisis dengan menggunakan Trikotomi Relasi Semiotika Pierce yaitu ikon, indeks, dan simbol. Ikon digunakan untuk dapat mengkaji lingkungan sosial dan profesi wanita dalam cerpen, indeks digunakan untuk mengkaji penyimpangan sosial, status sosial, dan gangguan psikologi anak, sedangkan simbol digunakan untuk mengkaji mengenai gaya hidup masyarakat marjinal perkotaan yang juga terlihat dari lingkungan tempat tinggal Sandra.

$$
\text { Hasil analisis tersebut }
$$
mengungkapkan bahwa cerpen tersebut merupakan perwakilan atau representasi dari fenomena-fenomena sosial yang ada di antara mayarakat kultur Indonesia. Sehingga, beberapa kritik sosial yang berhasil dikaji untuk merespon hasil telaah sistem tanda semiotika Pierce tersebut di antaranya mengenai bentukbentuk penyimpangan sosial pada masyarakat marjinal ibukota dan dampaknya terhadap diri sendiri, orang lain, maupun masyarakat.

\section{REFERENSI}

Artanti, Y., Sofyanti, D., Reza, M. D., \& Hartanti, W. (2020). Eksistensi Diri Tiga Perempuan dalam Trois Femmes Puissantes Karya Marie Ndiaye. Litera, 19 (3), 487-503. Christina. (2017). Sebuah Analisis Semiotik Logo Koko Cici 
Indonesia (Penguatan Identitas dalam Koko Cici). SEMIOTIKA: Jurnal Komunikasi, 10 (2), 241266.

Damono, S. D. (1978). Sosiologi Sastra (Sebuah Pengantar Ringkas). Jakarta: Depdikbud.

Dewi, M. C. (2013). Representasi Pakaian Muslimah dalam Iklan (Analisis Semiotika Charles Sanders Peirce pada Iklan Kosmetik Wardah di Tabloid Nova). Jurnal Komunikasi PROFETIK, 6 (2), 63-72.

Fitria, R. (2017). Analisis Semiotika

Charles Sanders Peirce dalam Iklan Kampanye Pasangan Calon Gubernur dan Wakil Gubernur Provinsi Bengkulu Tahun 2015. Manhaj, 1 (1), 43-49.

Hendri, Z. (2004). Pemanfaatan Semiotik Visual untuk Memahami Karya Seni Rupa. Imaji, 2 (1), 101-112.

Jasnain, T. (2017). Tindak Tutur Ridwan Remin pada Stand $U p$ Comedy Indonesia Season 7 Kompas TV Edisi Juni 2017. Basastra: Jurnal Bahasa, Sastra, dan Pengajarannya, 8 (2), 453-464.

Kadir, H. \& Palilati, J. (2017). Ikonitas Perempuan dalam Novel Grafis Embroideries Karya Marjane Satrapi. Litera, 16 (2), 318-328. Nurgiyantoro, B. (2005). Teori Pengkajian Fiksi. Yogyakarta: Gajah Mada Press.

Piliang, Y.A. (2010). Hipersemiotika: Tafsir Cultural Studies atas
Matinya Makna. Yogyakarta: Jalasutra.

Reinaldy, D. (2017). Gambaran Masyarakat Rusia Abad XIX dalam Cerpen Munafik Karya Anton Chekov Versi Koesalah Subagyo Toer Melalui Jalur Logika Pierce. Jurnal Sasindo Unpam, 4 (1), 39-61.

Sugiwardana, R. (2014). Pemaknaan Realitas serta Bentuk Kritik Sosial dalam Lirik Lagu Slank. Skriptorium, 2 (2), 86-94.

Supriyono. (2020). Novel American Wife Sittenfeld Karya Elizabeth Curtis: Pengaruh LakiLaki terhadap Perempuan. Basastra: Jurnal Bahasa, Sastra, dan Pengajarannya, 8 (2), 273280.

Taqiyya, K. F. K., Udasmoro, W., \& Firmonasari, A. (2020). Peliyanan terhadap Perempuan Dunia Ketiga pada Ruang Seksual dalam Novel Plateforme Karya Michel Houellebecq. Litera, 19 (3), 457-469.

Wellek, R., \& Warren, A. (1995). Teori Kesusastraan. Diterjemahkan Melani Budianta) Jakarta: Gramedia.

Wibowo, E. (2017). Makna Semiotik dalam Novel Anomie Karya Rilda A. Oe. Taneko. Jentera: Jurnal Kajian Sastra, 6 (2), 129-139. 